University of Nebraska - Lincoln

DigitalCommons@University of Nebraska - Lincoln

Nebraska Game and Parks Commission -- Staff

Research Publications

Nebraska Game and Parks Commission

January 1977

\title{
PRELIMINARY SURVEY OF HEAVY METAL CONTAMINATION OF CHANNEL CATFISH IN NEBRASKA
}

David Oates

Nebraska Game and Parks Commission, Lincoln, Nebraska

Norman Stucky

Nebraska Game and Parks Commission, Lincoln, Nebraska

Follow this and additional works at: https://digitalcommons.unl.edu/nebgamestaff

Part of the Environmental Sciences Commons

Oates, David and Stucky, Norman, "PRELIMINARY SURVEY OF HEAVY METAL CONTAMINATION OF CHANNEL CATFISH IN NEBRASKA" (1977). Nebraska Game and Parks Commission -- Staff Research Publications. 14.

https://digitalcommons.unl.edu/nebgamestaff/14

This Article is brought to you for free and open access by the Nebraska Game and Parks Commission at DigitalCommons@University of Nebraska - Lincoln. It has been accepted for inclusion in Nebraska Game and Parks Commission -- Staff Research Publications by an authorized administrator of DigitalCommons@University of Nebraska - Lincoln. 


\title{
PRELIMINARY SURVEY OF HEAVY METAL CONTAMINATION OF CHANNEL CATFISH IN NEBRASKA
}

\author{
David Oates and Norman Stucky \\ Nebraska Game and Parks Commission \\ Lincoln, Nebraska 68503
}

\begin{abstract}
The concentration of six heavy metals in channel catfish (lctalurus punctatus) fillets from seven watersheds in Nebraska - have been measured. With the exception of mercury, in no instance did levels exceed limits set by regulatory agents. Also, with the exception of mercury, concentrations of heavy metals did not differ significantly in the agricultural and industrial areas. Trans. Kansas Acad. Sci., vol. 80 (1-2), 197 ?.
\end{abstract}

\section{INTRODUCTION}

During the past decade accumulations of heavy metal residues have been found in soil, water, and living organisms. While heavy metals occur naturally and in some cases are essential for living organisms, even these can be harmful or lethal if concentrations exceed a limited useable range. Certain metals such as cadmium, lead, and mercury have no known physiological use, and are cummulative and toxic (Bowen, 1966).

The two most notorious toxic metals are lead and mercury. Children have suffered from lead poisoning as a result of ingesting lead-based paint. Concern for lead poisoning in infants led to the establishment of a $0.3 \mathrm{ppm}$ level of tolerance in evaporated milk by the Food and Drug Administration. Within the last two decades, mercury has received notoriety. Mercury was responsible for permanent brain damage and even the death of 110 people in Japan who had eaten fish contaminated by a mercury-laden industrial effluent (Sport Fishing Institute, 1970). In the field of agriculture, mercury compounds were used extensively as fungicides. Secondary mercury poisoning was evidenced when a family from New Mexico consumed pork fattened with mercury-treated seed corn (Furrer, 1970).

The Food and Drug administration has set a $0.5 \mathrm{ppm}$ tolerance level for residual mercury in fish tissue. This guideline led to the closing of several lakes and rivers to commercial and recreational fishing in the United States during 1969 and 1970. Similar closures occurred in Sweden and Canada (C \& E News, 1970; Conservation News, 1970; and SFI Bulletin, 1969). The game bird season in 1970 was cancelled in Alberta, 
Canada when mercury was detected in upland game birds (Nuclear News, 1970).

Because Nebraska is predominantly an agricultural state, concern was expressed that fish in intensive farming areas could contain excessive mercury residues originating from the fungicidal organo mercury compounds used in the treatment of seed. In addition, the effluents from a number of industries throughout the state were suspected of containing mercury, cadmium, copper, chromium, lead and zinc.

The objective of this cursory study was to determine whether channel catfish from areas of intensive agriculture and industry contain excessive residues of any of the aforementioned heavy metals. This preliminary study would also establish a baseline which could be utilized for future reference.

\section{METHODS AND MATERIALS}

The channel catfish (Ictalurus punctatus) was selected as the indicator species primarily because of its value as a sport and food fish. This species is distributed statewide and is characterized by omnivorious food habits which makes possible the uptake of residues via the gastrointestinal route in addition to absorption through the gills and body.

Approximately ten channel catfish were collected from each of seven selected watersheds throughout the state (Table 1). Two sites were located in the southwest in a predominately dryland agricultural area where wheat was the primary crop; two were in the central part of the state where irrigated corn was predominant; and the remaining sites were in areas where industry could also possibly contribute to watershed contamination.

An attempt was made to collect creelable channel catfish of varying sizes. Immediately after collection the catfish were wrapped in aluminum foil and frozen. A fillet, which included the lateral musculature between the anterior insertion of the dorsal fin and a point midway between the adipose and caudal fin served as the sample to be analyzed from each fish. A Virtis blender was used to homogenize the fillet. Subsequent analyses were performed on subsamples taken from the homogenate.

All samples were analyzed via atomic absorption spectrophotometry. A flameless technique devised by the Dow Chemical Company, 1970, was used for mercury analysis. Lead was analyzed through the use of an organic extraction technique (Yeager et al., 1971). Chromium, cadmium, copper, and zinc analyses were carried out by solubilizing samples with nitric acid diluted to a volume of 25 milliliters and aspirated directly into either a 303 Perkin-Elmer or Jarrell-Ash Model 810 atomic absorption spectrophotometer. All samples were analyzed using wave lengths recommended by Perkin-Elmer. 
Table 1. Location of Collecting Sites and Potential Souce of Heavy Metals In Each System.

\begin{tabular}{llll}
\hline Drainage & County & Section, T., R. & Source of Heavy Metals \\
\hline Frenchman River & Chase & $37-6 \mathrm{~N}-39 \mathrm{~W}$ & Agriculture - Wheat \\
Stinking Water Creek & Hayes & $27-35 \mathrm{~W}-6 \mathrm{~N}$ & Agriculture - Wheat \\
Little Blue River & Nuckolls & $20-4 \mathrm{~N}-6 \mathrm{~W}$ & Agriculture - Rowcrop \\
W. Fork Big Blue River & Seward & $31-10 \mathrm{~N}-\mathrm{IE}$ & Agriculture- Rowcrop \\
Big Blue River & Gage & $24-4 \mathrm{~N}-5 \mathrm{E}$ & Industry \& Agriculture \\
Salt Creek & Saunders & $10-12 \mathrm{~N}-9 \mathrm{E}$ & Industry \& Municipal \\
Loup River & Platte & $35-16 \mathrm{~N}-1 \mathrm{E}$ & Industry \& Agriculture \\
\hline
\end{tabular}

\section{RESULTS AND DISCUSSION}

The mean residual concentrations of the heavy metals found in channel catfish fillets collected from the selected watersheds are presented in Table 2. Additional data presented include the range and standard deviation of residues in each watershed. These data were subjected to an analysis of variance in conjunction with the Duncan multiple range test (DMRT) to determine whether residual concentrations present in predominately agricultural areas differed from those present in watersheds receiving industrial effluent.

Currently there are no Food and Drug Administration tolerance limits on cadmium, chromium, copper, lead, and zinc residue levels in fish. The Canadian Food and Drug Directorate has established tolerance in food products for lead, copper and zinc of 10,100, and $100 \mathrm{ppm}$ respectively. By this standard of tolerance, the lead, copper, and zinc residues found in fish from Nebraska watersheds pose no health hazard.

In catfish from Nebraska waters cadmium concentrations averaged $0.18 \mathrm{ppm}$ and ranged up to $0.44 \mathrm{ppm}$. These values are higher than those found by both Uthe and Bligh (1971) and Kleinert et al., (1974) for Great Lakes and Wisconsin fish. However, Tong et al. (1972) in New York and Hesse and Evans (1972) in Michigan found values ranging to $0.17 \mathrm{ppm}$ and $0.3 \mathrm{ppm}$ respectively.

Chromium concentrations were also somewhat higher in Nebraska fish (0.01 to $0.84 \mathrm{ppm})$. Concentrations in Wisconsin fish ranged to 0.42 ppm (Kleinert et al., 1974) and to 0.5 ppm in Michigan fish (Hesse and Evans, 1972).

Uthe and Bligh (1971) found copper concentrations from 0.50 to 1.28 ppm in fish from the Great Lakes area. Nebraska catfish contained up to $2.42 \mathrm{ppm}$ copper, which is higher, but still well below a $100 \mathrm{ppm}$ tolerance level. 
Lead levels in Nebraska fish (0.05 to 0.75 ppm) were lower than those found by Kleinert et al. (1974) in Wisconsin (up to $4.31 \mathrm{ppm}$ ) and those found by Hesse and Evans (1972), in Michigan (up to $0.9 \mathrm{ppm}$ ).

Zinc levels were also a little lower in Nebraska (5.10 to 014.09 ppm) than in other states. Kleinert et al. (1974) reported 3.2 to $18.3 \mathrm{ppm}$ in Wisconsin fish. Findings by Tong et al. (1972) in New York and Hesse and Evans (1972) in Michigan were 1.2 to $38 \mathrm{ppm}$ and 6 to $45 \mathrm{ppm}$ zinc respectively.

Uthe and Bligh (1971) found that heavy metal concentrations in a specific area varied between species. Therefore, one should note that in the above comparisons for cadmium, chromium, copper, lead and zinc concentrations this report refers only to channel catfish. However, fish species occupying a similar trophic level to channel catfish were examined by investigators referred to above.

Although an analysis of variance revealed a significant difference $(0.05)$ in residual concentrations of chromium, zinc, and lead between the selected watersheds; the Duncan multiple range test failed to show that this difference existed between watersheds in predominately agricultural areas and those receiving municipal and industrial effluents along with agricultural runoff.

The mean residual concentrations of mercury detected in the muscle tissue from each watershed was well below the 0.5 tolerance level established by the Food and Drug Administration (Table 1). Only one fish contained a concentration $(0.85 \mathrm{ppm})$ in excess of the established maximum level. That fish was collected from the Big Blue River just below a chlor-alkali plant where mercury is used as a catalyst in the production of chlorine. Concentration levels in the other nine fish from the Big Blue River ranged from $0.02 \mathrm{ppm}$ to $0.24 \mathrm{ppm}$. Our values ranging from 0.01 to $0.85 \mathrm{ppm}$ are similar to the values found in catfish from the neighboring state of lowa by Morris et al., 1971. lowa's concentrations ranged from 0.04 to $0.45 \mathrm{ppm}$.

Mercury is known to be cummulative, therefore the size of a fish may be correlated with the concentration of mercury present in the muscle tissue. A calculated coefficient of -.13 for the residue present and the total length of each fish indicated no such correlation for the seventy fish examined in this study.

An analysis of variance indicated a highly significant $(P=.001)$ difference between watersheds for mercury concentrations present in channel catfish muscle tissue. Duncans multiple range test indicated a similar concentration of mercury was present in catfish in the Little Blue River, the Frenchman River, and Stinking Water Creek; and that this concentration was significantly lower $(0.05)$ than that found in Salt Creek, Loup River, Big Blue River, and West Fork of Big Blue River. Because the aforementioned watersheds with the low mercury content are in predominately agricultural areas, while those remaining watersheds also receive significant municipal and industrial effluents, it could 
TABLE 2. Concentrations of Heavy Metal Residues in Channel Catfish Muscle From Selected Watersheds. Throughout Nebraska, 1974

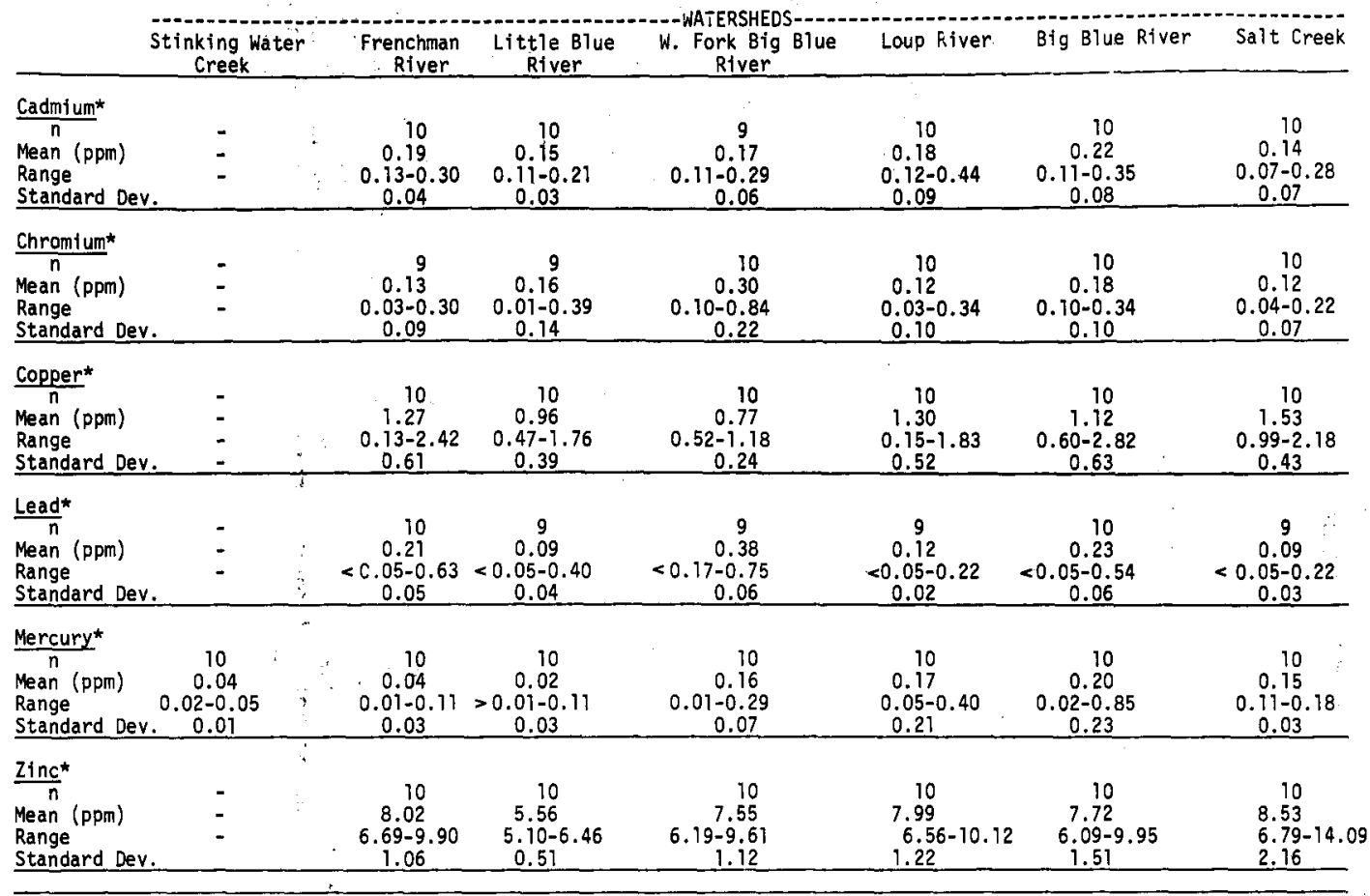

*Results expressed in ppm. wet weight basis. 
be concluded that such effluents are more cause for concern of mercury entering a watershed than the agricultural use of mercurial compounds.

\section{ACKNOWLEDGEMENTS}

This study was supported by funds supplied by the Federal Aid in Sport Fish Restoration Act, under Dingell-Johnson Project F-4-R and the Nebraska Game and Parks Commission. The use of atomic absorption spectrophotometers at Nebraska Wesleyan University and the University of Nebraska was greatly appreciated.

\section{REFERENCES}

Bowen, N.J.M. 1966. Trace elements in biochemistry. Academic Press, New York, New York. 241pp.

Chemical \& Engineering News. 1970. Mercury: wiping out an industry. April 13, p. 9.

Conservation News, 1970. Mercury, everywhere. July 15, p. 9.

Dow Chemical Company, 1970. Determination of mercury by atomic absorption spectrophotometric method, Midland, Michigan. CAS-AM-70.10.

Furrer, J.D. 1970. Another round on the mercury merry-go-round. Pesticide Pointers, Cooperative Extension Service, University of Nebraska, College of Agriculture. $7(10)$

Hesse, J.L. and E.D. Evans, 1972. Heavy metals in surface waters, sediments, and fish in Mich. Michigan Water Resources Commission, Dept. Natur. Resour. $58 \mathrm{p}$.

Kleinert, S.J., P.E. Degruse, and J. Ruhland, 1974. Concentration of Metals in Fish. Tech. Bull. \#74. Wis. Dept. Natur. Resour. 15p.

Morris, R.L., L. Johnson, and D. W. Ebert, 1971. Mercury concentration of Metals in Fish. Tech. Bull. \#74. Wis. Dept. Natur. a Resour. 15p.

Morris, R.L., L. Johnson, and D.W. Ebert, 1971. Mercury concentration in fish from lowa rivers. Report \#72-16 from State Hygienic Lab. U. of lowa, lowa City, lowa 52240.

Nuclear News, 1970. MTR to measure $\mathrm{Hg}$ in game birds. 13(8):34.

Sport Fisheries Institute Bulletin, 1969. Mercury pollution threat.

Sport Fishing Institute Bulletin. May, 1970, Sport Fishing Institute, Washington, D.C. \#214.

Tong, S.C., W. H. Gutenmann, D.J. Lisk, G.E. Burdick and E.H. Harris, 1972. Trace metals in New York State Fish. N.Y. Fish and Game J. 19(2):123-131.

Uthe, J.F. and E.G. Bligh, 1971. Preliminary survey of heavy metal contamination of Canadian fresh water fish. J. Fish. Res. Board of Can. 28(5):786-788.

Yeager, D.W., J. Cholak, and E.W. Henderson, 1971. Determination of lead in biological and related material by atomic absorption spectrophotometry. Environmental Science and Technology. 5(10):1020. 